\title{
Research on The Teachers' Views About The Use of Alternative Assessment and Evaluation Methods for Physical Education And Sports Courses
}

\author{
Onur Özkoparan ${ }^{1}$, Mehmet İnan ${ }^{2}$
}

\author{
${ }^{1}$ Amasya Gümüşhacıköy Hasan Coci High School, ozkoparanonur@hotmail.com \\ ${ }^{2}$ Marmara University, minan@ marmara.edu.tr
}

Received: 08.01.2018

Accepted: 31.01 .2018

Online Published: 08.03.2018

doi: 10.30655/besad.2018.0

\begin{abstract}
The purpose of this research was to determine the frequency of using alternative assessment and evaluation methods of the physical education teachers working in secondary schools and to determine their opinions about these methods, according to some demographic characteristics of teachers. Quantitative and qualitative data collection techniques, designed according to the research screening model, were utilized. The sample of the research was composed of 257 physical education teachers working in the state and private secondary schools in Istanbul province in 2014-2015 academic year. In the collection of the data: "authentic assessment and evaluation tools usage frequency survey" and "semi-structured interview questions" were used. According to the obtained data; there are significant differences in the frequency of physical education teachers' usage of alternative assessment and evaluation methods based on the level of in-service training, which they have attended. It was observed that demonstration was the most frequently used method, then respectively, performance evaluation, observation, control list, grading scale, and interview were the frequently used by physical education teachers compared to other alternative assessment and evaluation methods. Besides, physical education teachers indicated the alternative assessment and evaluation methods which they widely used respectively as control list, demonstration and grading scale, observation, interview, group evaluation, peer-evaluation, and self-evaluation, project, rubric, and drama. According to most of the physical education teachers, the greatest challenge was time insufficiency in implementing alternative assessment and evaluation methods.
\end{abstract}

Key Words: Alternative Assessment and Evaluation Methods, Teacher Views

\section{Beden Eğitimi ve Spor Derslerinde Alternatif Ölçme-Değerlendirme Yöntemlerinin Kullanılmasına İlişkin Öğretmen Görüşlerinin İncelenmesi}

\section{$\ddot{\mathbf{O} z}$}

$B u$ araştırma ile ortaokullarda görev yapan Beden Ĕgitimi öğretmenlerinin alternatif ölçme ve değerlendirme yöntemlerini kullanma sıklıkları ile bu yöntemlere yönelik görüşlerinin saptanması ve ögretmenlerin bazı demografik özelliklerine göre farklllaşma durumlarının tespit edilmesi amaçlanmıştır. Araştırma tarama modeline göre tasarlanmış, nicel ve nitel veri toplama tekniklerinden yararlanılmıştır. Araştırmanın örneklemini, 2014-2015 Ë̆itim-Öğretim yılında İstanbul ilindeki devlet ve özel ortaokullarında görev yapan 257 Beden Eğitimi ögretmeni oluşturmuştur. Verilerin toplanmasında: Kıllç (2013) 'a ait olan "otantik ölçme ve değerlendirme araçlarına yönelik kullanma sıklı̆̆ anketi" ile "yarı yapılandırılmış görüşme formu” kullanılmıştır. Elde edilen verilere göre; Beden Ĕ̈itimi ögrretmenlerinin genel olarak alternatif ölçme ve değerlendirme yöntemlerini kullanma sıklkkları arasında hizmet içi eğitim alma durumuna göre anlamlı farklılıklar vardır. Beden Ĕ̈itimi öğretmenleri en sik "gösteri" yöntemini daha sonra ise sira ile "performans değerlendirme, gözlem, kontrol listesi, dereceleme ölçeği ve görüşme" yöntemlerini diğer alternatif ölçme ve değerlendirme yöntemlerine göre 
daha sık kullandıklarını belirtmişlerdir. Ayrıca Beden Eğitimi öğretmenleri sıklıkla kullandıkları alternatif ölçme ve değerlendirme yöntemlerini sırasıla performans değerlendirme, kontrol listesi, gösteri ve dereceleme ölçeği, gözlem, Görüssme, grup değerlendirme, akran dĕgerlendirme ve öz değerlendirme, proje, rubrik ve drama olarak belirtmişlerdir. Beden Eğitimi ögretmenlerinin birçoğuna göre alternatif ölçme ve değerlendirme yöntemlerinin uygulanmasında yaşanan en büyük zorluk; zaman yetersizliği yaşamalarıdır.

Anahtar Kelimeler: Alternatif Ölçme ve Değerlendirme Yöntemleri, Öğretmen Görüşleri

\section{Giriş}

Eğitim, bireyin davranışında kendi yaşantısı yoluyla ve kasıtlı olarak istendik değişme meydana getirme sürecidir (Ertürk, 2013, s.13). Bu süreç içerisinde insan çeşitli değişsimler yaşar. Ertürk'e göre (2013), bir organizma olarak yaşamına başlayan birey fiziki, sosyal ve kültürel çevresiyle etkileşimlerinin ürünü olarak bazı alışkanlıklar kazanır ve bunları diğer insanlarla paylaşır. Öyleyse planlı eğitim ile bireyin etkileşimde bulunduğu çevre şartlarını daha geniş ve büyük ölçüde kontrol altına alabildiğimiz oranda istediğimiz insanı yaratma şansımız artacak demektir.

Eğitim alanında ortaya çıkan yapılandırmacı yaklaşım anlayışı, alışılmış/geleneksel öğrenme, öğretme ve ölçme değerlendirme yaklaşımlarını derinden etkilemiştir. Bilgi kuramındaki (epistemoloji) yeni anlayışlar ile yürütülen araştırmaların sonucu olarak, bireylerin bilgiyi anlamlandırma süreçlerinde farklılıkların ortaya çıkması, alternatif ölçme ve değerlendirme yöntemlerinin kullanılmasını zorunlu kılmıştır (Geçit, 2012, s.161).

Eğitimde ölçme değerlendirme alanında bazı değişimler yaşanmaktadır. $\mathrm{Bu}$ değişimlerden birkaçı şöyle sıralanabilir (Kayapınar, Savaş, 2012, s.1):

1) Öğretmenin belirlediği ölçütlerle gerçekleşen tekdüze sınavlar yerine, öğrenciler ve öğretmenin birlikte karar verdikleri sınav şekline geçilmiştir.

2) Öğrencilerin yapılan sınavlarla programın öngördüğü içeriği kazanıp kazanmadıklarının belirlenmesi yerine, önceden kararlaştırılmış yeterliklere ulaşma düzeyi anlaşılmaya çalışılmaktadır. Bir diğer ifade ile bununla; sadece eğitim programında yer alan öğrenme hedeflerinin test edilmesi değil, öğrencilerin bireysel farklılıklarının da dikkate alındı̆̆ öğrenme çıktılarının belirlenmesi hedeflenmektedir.

Yakın geçmişte Türkiye'de de özellikle eğitim kurumlarında ölçme-değerlendirme biçimlerinde değişimler yaşanmaktadır. Özellikle Milli Eğitim Bakanlığı öğretmenlerden ölçme ve 
değerlendirme yöntemleri konusunda alternatif yolları kullanmalarını istemektedir. Bunu özellikle 2004 yılında hazırlamış olduğu öğretim programlarında görmekteyiz.

Türkiye'de 2004 yılında MEB (2006) tarafından yapılandırmacı yaklaşımla ilgili eğitimöğretim programları benimsenmiştir. Yapılandırmacı yaklaşımla beraber alternatif ölçme ve değerlendirme yöntemlerinden söz edilmeye başlanmıştır. "Alternatif" sözcüğü, bir değerlendirme yönteminin öğretim sürecinin dışında bırakılarak, onun yerine bir diğerinin kullanılması gerektiği anlamında düşünülmemelidir. Öğretim sürecinde, öğrenci başarısının belirlenmesindeki amaca bağlı olarak farklı değerlendirme yöntemleri kullanılmalıdır. $\mathrm{Bu}$ anlamda bütün değerlendirme yöntemleri birbirinin alternatifidir (Doğan ve ark., 2014, s.4).

Beden Eğitimi ve Spor derslerinde kullanılması önerilen alternatif ölçme değerlendirme yöntemleriyle ilgili olarak alan yazındaki araştırmaların çok sınırlı oluşu bu konunun araştırılmasını ilgi çekici kılmaktadır. Bu araştırmada Beden Eğitimi öğretmenlerinin alternatif ölçme-değerlendirme yöntemleriyle ilgili yaşadıkları sorunların incelenmesi hedeflenmektedir.

Araştırmanın amacı doğrultusunda aşağıdaki sorulara yanıt aranmıştır:

- Beden Eğitimi öğretmenlerinin alternatif ölçme ve değerlendirme yöntemlerini kullanma sıklıkları nedir?

Beden Eğitimi öğretmenlerinin alternatif ölçme ve değerlendirme yöntemlerini kullanma sıklıkları:

$\checkmark$ Görev yapılan okul türüne göre farklılaşmakta mıdır?

$\checkmark$ Hizmet içi eğitim alma durumuna göre farklılaşmakta mıdır?

$\checkmark$ Beden Eğitimi öğretmenlerinin derslerinde kullandıkları ölçme ve değerlendirme yöntemlerini tercih etme nedenleri nelerdir?

$\checkmark$ Beden Eğitimi öğretmenleri alternatif ölçme ve değerlendirme yöntemleri konusunda yeterince bilgi sahibi olduklarını düşünüyorlar mı?

$\checkmark$ Beden Eğitimi öğretmenleri alternatif ölçme ve değerlendirme yöntemleriyle ilgili herhangi bir hizmet içi eğitim aldılar mı? Aldıkları eğitimin yeterliliğine ilişkin düşünceleri nelerdir?

$\checkmark$ Beden Eğitimi öğretmenleri programdaki alternatif ölçme ve değerlendirme yöntemlerinden en sık hangilerini kullanıyorlar? $\mathrm{Bu}$ yöntemleri tercih etme nedenleri nelerdir?

$\checkmark$ Beden Eğitimi öğretmenlerinin alternatif ölçme değerlendirme yöntemlerini uygularken yaşadıkları zorluklar nelerdir? 


\section{Yöntem}

\section{Araştırma Modeli:}

Araştırmada tarama modeli kullanılmış ve hem nicel hem de nitel boyutları tercih edilmiştir.

Genel tarama modelleri, çok sayıda elemandan oluşan bir evrende, evren hakkında genel bir yargıya varmak amacı ile evrenin tümü ya da ondan alınacak bir grup üzerinde yapılan düzenlemelerdir (Karasar, 2005, s.79).

\section{Araştırma Grubu:}

Araştırmanın grubunu 2014-2015 eğitim-öğretim y1lında İstanbul ilindeki devlet ve özel ortaokullarında görev yapan Beden Eğitimi öğretmenleri arasından seçkisiz örnekleme yöntemiyle seçilen 257 öğretmen oluşturmuştur (Tablo1). Araştırmada nitel veri toplama arac1 olarak "Yarı-Yapılandırılmış Görüşme Formu” kullanılmıştır. Nitel veriler, 25 Beden Eğitimi öğretmeninden elde edilmiştir. Görüşme, seçkisiz örnekleme yöntemiyle seçilmiş gönüllü öğretmenlerle, bireysel olarak yüz yüze yapılmış ve yaklaşık 20'şer dakika sürmüştür. Görüşmede öğretmenlerin izni doğrultusunda ses kayıt cihazı ve görüşme formu kullanılmıştır. Gönüllülük esasına dayalı olarak uygulama için olumlu yönde tutum gösteren okullar belirlenmiş ve bu okullarda görev yapan öğretmenler örnekleme dâhil edilmiştir. Bu yöntemin ve nitel veri için belirlenen öğretmen sayısının tercih edilmesindeki temel neden evrenin büyüklügü ve özellikle kullanılan ölçme araçlarının yapısından kaynaklı ekonomik nedenlerdir.

Tablo 1. Araştırma Örneklemine Ait Demografik Özellikler Tablosu

\begin{tabular}{llcc}
\hline & Gruplar & f & \% \\
\hline Cinsiyet & Kadın & 114 & 44.4 \\
& Erkek & 143 & 55.6 \\
\hline Okul Türü & Devlet & 167 & 65 \\
& Özel & 90 & 35 \\
\hline Hizmet içi eğitim alma & Evet & 80 & 31.1 \\
& Hayır & 177 & 68.9 \\
Toplam & & $\mathbf{2 5 7}$ & $\mathbf{1 0 0}$ \\
\hline
\end{tabular}

\section{Veri Toplama Araçları:}

\section{Alternatif Ölçme Dĕgerlendirme Yöntemleri Kullanma Sıklı̆̆ı Anketi:}

Araştırmada Beden Eğitimi Öğretmenlerinin alternatif ölçme-değerlendirme yöntemlerini kullanmalarına yönelik görüşlerini belirlemeye yönelik olarak Kılıç'ın (2014), “Otantik Ölçme ve Değerlendirme Araçları Kullanma Sıklığı Anketi” kullanılmıştır. Ankette 22 alternatif ölçme ve değerlendirme yöntemi yer almaktadır. Ankette yer verilen her bir alternatif ölçme ve değerlendirme yöntemi için 0 “bilgim yok”, 1 "hiçbir zaman”, 2 “çok az”, 3 “zaman zaman”, 4 
“çoğu zaman” ve 5 "her zaman” şeklinde bir dereceleme çizelgesi oluşturulmuştur. Ankette öğretmenlerden istenen, verilen alternatif ölçme ve değerlendirme yöntemini derslerinde kullanma sıklıklarına uygun olarak herhangi bir seçeneği işaretlemeleridir. Her bir alternatif ölçme ve değerlendirme yöntemi için işaretlenen puan arttıkça kullanım sıklığının da fazla olacağı anlamına gelmektedir.

Alternatif Ölçme ve Değerlendirme Yöntemine Yönelik Görüşme Formu: Araştırmanın nitel boyutunda yarı yapılandırılmış görüşme tekniği kullanılmıştır. "Alternatif Ölçme ve Değerlendirme Yöntemine Yönelik Görüşme Formu” öğretmenlerin alternatif ölçme ve değerlendirme yöntemine yönelik görüşlerini ayrıntılı bir şekilde incelemek için geliştirilmiştir. Araştırmaya katılan Beden Eğitimi öğretmenlerine, yarı yapılandırılmış görüşme formu kullanılarak görüşmeler yapılmıştır. Hazırlanan görüşme formunda öğretmenlerin cevaplamaları gereken 5 adet açık uçlu soru yer almaktadır.

1) Beden Eğitimi derslerinde kullandığınız ölçme ve değerlendirme yöntemlerini tercih etme nedeniniz nedir?

2) Alternatif ölçme ve değerlendirme yöntemi konusunda yeterince bilgi sahibi olduğunuzu düşünüyor musunuz?

3) Alternatif ölçme ve değerlendirme yöntemiyle ilgili herhangi bir hizmet içi eğitim aldınız mı? Aldıysanız yeterliliğiyle ilgili ne düşünüyorsunuz?

4) Yeni programdaki alternatif ölçme ve değerlendirme yöntemlerinden en çok hangilerini kullanmaktasınız?

5) Alternatif ölçme değerlendirme yöntemlerini uygularken yaşadığınız zorluklar nelerdir?

\section{Veri Toplama Süreci:}

Araştırmada nicel verilerin toplanmasında kullanılan "Alternatif Ölçme ve Değerlendirme Yöntemleri Kullanma Sıklığı Anketi” hazırlandıktan sonra, İstanbul ili Anadolu yakası ve Avrupa yakasında, araştırma kapsamında seçkisiz örnekleme yöntemiyle seçilen devlet ve özel ortaokullarında görev yapan Beden Eğitimi öğretmenlerine uygulanmıştır. Uygulama sonucunda toplanan verilerden eksik ve yanlış doldurulanlar elendikten sonra geriye kalan veriler değerlendirmeye alınmıştır. Araştırmada nitel veri toplama aracı olarak "YarıYapılandırılmış Görüşme Formu” kullanılmıştır.

\section{Verilerin Analizi:}

Araştırmada toplanan nicel verilerin analizinde istatistik paket programı olan SPSS'in 22. versiyonu kullanılmıştır. Nicel verileri analiz etmek üzere hangi istatistik tekniklerin 
kullanılması gerektiğini belirlemek üzere öncelikle toplanan verilerin dağılımının normallik gösterip göstermediği Tek Örneklem Kolmogorov-Smirnov testi kullanılarak belirlenmiştir. Araştırmada toplanan nicel verileri analiz etmek üzere parametrik olmayan istatistik testlerin kullanılmasına karar verilmiştir. Araştırmanın alt amaçlarına göre kullanılan parametrik olmayan testler şunlardır: Araştırmanın birinci alt amacı olan "Beden Eğitimi Öğretmenlerinin alternatif ölçme ve değerlendirme yöntemlerini kullanma sıklıkları nedir?" sorusuna yanıt bulmak amaciyla toplanan nicel veriler üzerinde aritmetik ortalama ve standart sapma gibi betimsel istatistik analizi uygulanmıştır. Diğer alt amaçlarda Mann-Whitney U Testi ya da Kruskal Wallis testi kullanılmış, Kruskal Wallis Testi sonucunda anlamlı farklılık çıkan gruplar üzerinde de Post Hoc testi olarak Mann-Whitney U Testi kullanılmıştır.

Nitel verilerin analizinde ise, öğretmenlerin "Yarı yapılandırılmış görüşme formuna" (YYGF) verdikleri cevapların analizine değinilmiştir. YYGF'den elde edilen nitel verilerin analizinde içerik analizi yöntemi kullanılmıştır. YYGF ile elde edilen verilerin analizine formların numaralandırılması ile başlanmıştır. Her öğretmene bir kod verilmiştir: Öğretmen1, Öğretmen2, Öğretmen3...gibi. (Ö1, Ö2, Ö3,.....) Daha sonra formlar iki kere okunarak verilere ait kategoriler ve yapılacak doğrudan alıntılar belirlenmiştir. Her soru için kodlar oluşturulmuştur. Kategorilere ait cevaplar belirlenmiş, belirlenen kodlar Excel programına işlenmiş ve aynı kategori içinde bir araya getirilmiştir. YYGF'ye ait tüm nitel veriler belirlenen kategorilere işlenmiş, kontrolleri yapılmış ve frekansları hesaplanıp, yapılan işlemlerin teyidi için alanda uzman birine danışılmıştır. 32 kod ve 6 kategoriden oluşan ilk liste yaratılmıştır. Araşıırmanın güvenirliğini arttırmak için oluşturulan alt kodlar ve kategoriler ayrı olmak üzere bir uzmana sunulmuştur. Uzmana sunulan listede hangi alt kodun hangi kategori altına eklendiği gizlenmiş ve uzmanın 32 alt kodu 6 kategoriden dilediğine eşleştirmesi istenmiştir. Araştırmacı ve uzman tarafından oluşturulan iki liste karşılaştırılmış ve uzmanın bir alt kodu farklı bir kategoriye eklediği anlaşılmıştır. Sonuç olarak, kodlayıcı güvenirliği 0.97 olarak hesaplanmıştır. $\mathrm{Bu}$ işlem için aşağıdaki formül kullanılmıştır: "Güvenirlik= ((Uzlaşılan kod sayıs1)) : (Uzlaşılan kod sayısı + Uzlaşılmayan kod sayısı))x 100" (Miles and Huberman, 1994). [Güvenirlik= $((31):(31+1)) \times 100 \Rightarrow=97 \%]$. Formlar ve oluşturulan kategoriler incelenmiş ve gerekli kontroller ve düzeltmeler yapıldıktan sonra YYGF'den elde edilen nitel bulgular yorumlanmıştır. 


\section{Bulgular}

\section{Nicel Bulgular:}

Beden Eğitimi öğretmenlerinin alternatif ölçme ve değerlendirme yöntemlerini kullanma sıklıklarına ilişkin aritmetik ortalama ve standart sapma değerlerine göre alternatif ölçme ve değerlendirme yöntemleri arasında en sık "gösteri” yöntemini $(\bar{X}=3,88)$ daha sonra ise sıra ile "performans değerlendirme $(\bar{X}=3,81)$, gözlem $(\bar{X}=3,62)$, kontrol listesi $(\bar{X}=3,44)$, dereceleme ölçeği $(\bar{X}=3,38)$ ve görüşme ( $\bar{X}=3,09)$ " yöntemlerini diğer alternatif ölçme ve değerlendirme yöntemlerine göre s1k kullandıkları görülmüştür (Tablo 2).

Tablo 2. Beden Eğitimi Öğretmenlerinin Alternatif Ölçme ve Değerlendirme Yöntemlerini Kullanma Sıklıklarına İlişkin Aritmetik Ortalama ve Standart Sapma Değerleri

\begin{tabular}{lccc}
\hline & $\mathrm{N}$ & $\bar{X}$ & $\mathrm{Ss}$ \\
\hline Gösteri & 257 & 3,88 & 1,07 \\
Performans Değerlendirme & 257 & 3,81 & 1,25 \\
Gözlem & 257 & 3,62 & 1,18 \\
Kontrol Listesi & 257 & 3,44 & 1,32 \\
Dereceleme Ölçeği & 257 & 3,38 & 1,31 \\
Görüşme & 257 & 3,09 & 1,25 \\
Proje & 257 & 2,91 & 1,20 \\
Grup Değerlendirme & 257 & 2,81 & 1,24 \\
Drama & 257 & 2,26 & 1,23 \\
Rubrik & 257 & 2,22 & 1,49 \\
Öz Değerlendirme & 257 & 2,14 & 1,34 \\
Akran değerlendirme & 257 & 2,06 & 1,15 \\
Poster & 257 & 2,01 & 1,27 \\
Portfolyo & 257 & 1,99 & 1,27 \\
Tutum Ölçeği & 257 & 1,67 & 1,29 \\
Kelime İlişkilendirme & 257 & 1,63 & 1,18 \\
Anekdot & 257 & 1,61 & 1,28 \\
Kavram haritası & 257 & 1,34 & 1,03 \\
Çengel Bulmaca & 257 & 1,16 & 0,97 \\
Yapılandırılmış Grid & 257 & 0,89 & 1,02 \\
Tanılayıcı Dallanmış Ağaç & 257 & 0,87 & 1,11 \\
Vee Diyagramı & 257 & 0,81 & 1,01 \\
\hline
\end{tabular}

Devlet ve özel okulda görev yapan Beden Eğitimi öğretmenleri arasında genel olarak alternatif ölçme ve değerlendirme yöntemlerini kullanma sıklıkları açısından anlamlı bir fark söz konusu değildir ( $p>0,05)$. Her iki okul türünde de görev yapan Beden Eğitimi öğretmenlerinin alternatif ölçme ve değerlendirme yöntemlerini genel olarak benzer sıklıkta kullandıkları söylenebilir (Tablo 3). 
Tablo 3. Okul Türüne Göre Beden Eğitimi Öğretmenlerinin Genel Olarak Alternatif Ölçme ve Değerlendirme Yöntemlerini Kullanma Sıklıklarındaki Farklılaşmayı Bulmak İçin Yapılan MannWhitney U Testi Sonuçları

\begin{tabular}{lccccc}
\hline \multicolumn{1}{c}{ Grup } & $\mathrm{N}$ & $\begin{array}{c}\text { Sira } \\
\text { Ortalamas1 } \\
(\text { SO) }\end{array}$ & $\begin{array}{c}\text { Sira Toplamı } \\
(\text { ST) }\end{array}$ & $\mathrm{U}$ & $\mathrm{P}$ \\
\hline Devlet & 167 & 132,37 & 22106,50 & 6951,50 &, 321 \\
Özel & 90 & 122,74 & 11046,50 & & \\
Toplam & 257 & & & & \\
\hline
\end{tabular}

Tablo 4'te görüldüğü gibi hizmet içi eğitim almış ve almamış Beden Eğitimi öğretmenleri arasında genel olarak alternatif ölçme ve değerlendirme yöntemlerini kullanma sıklıkları açısından anlamlı bir fark söz konusudur $(\mathrm{p}<0,05)$. Sıra ortalamalarına bakıldığında alternatif ölçme ve değerlendirme yöntemleri konusunda hizmet içi eğitim almış Beden Eğitimi öğretmenlerinin $(\mathrm{SO}=173,06)$ hizmet içi eğitim almamış öğretmenlere $(\mathrm{SO}=109,08)$ göre alternatif ölçme ve değerlendirme yöntemlerini genel olarak daha sık kullandıkları söylenebilir.

Tablo 4. Hizmet İçi Eğitim Alma Durumuna Göre Beden Eğitimi Öğretmenlerinin Genel Olarak Alternatif Ölçme ve Değerlendirme Yöntemlerini Kullanma Sıklıklarındaki Farklılaşmayı Bulmak İçin Yapılan Mann-Whitney U Testi Sonuçları

\begin{tabular}{lccccc}
\hline \multicolumn{1}{c}{ Grup } & $\mathrm{N}$ & $\begin{array}{c}\text { Sira } \\
\text { Ortalamas } \\
(\text { SO) }\end{array}$ & $\begin{array}{c}\text { Sira Toplamı } \\
(\text { ST) }\end{array}$ & U & P \\
\hline Evet & 80 & 173,06 & 19308 & 3555 &, $\mathbf{0 0 0}$ \\
Hayır & 177 & 109,08 & 13845 & & \\
Toplam & 257 & & & & \\
\hline
\end{tabular}

\section{Nitel Bulgular}

Araştırmaya katılan öğretmenlerin derslerinde kullandıkları ölçme ve değerlendirme yöntemlerini tercih etme nedenleri 6 alt kod altında toplanmıştır. Araştırmaya katılan öğretmenlerin büyük çoğunluğu kullandıkları yöntemleri tercih etme nedenlerini bu yöntemlerin kullanışı ı ve uygun olması olarak belirtmişlerdir (Tablo 5).

Tablo 5. Beden Eğitimi Öğretmenlerinin Kullandıkları Ölçme ve Değerlendirme Yöntemlerini Tercih Etme Nedenlerine Yönelik Düşünceleri

\begin{tabular}{llcc}
\hline Kategoriler & \multicolumn{1}{c}{ Alt Kodlar } & f & \% \\
\hline \multirow{2}{*}{ Tercih Etme Nedeni } & Kullanışlı ve Uygun & 11 & 32 \\
& Programda var(zorunluluk) & 7 & 20.5 \\
& Seviye belirleme-Öğrenciyi & 7 & 20.5 \\
& Tanıma & & \\
& Objektif ve güvenilir & 4 & 12 \\
& Yeterlilik (verimli) & 3 & 9 \\
& Somut veri elde etme & 2 & 6 \\
\hline
\end{tabular}


Alternatif ölçme ve değerlendirme yöntemine yönelik yeterince bilgi sahibi olup olmama durumuna ilişkin olarak, görüşme yapılan 25 öğretmenin 12'si alternatif ölçme ve değerlendirme yöntemine yönelik yeterince bilgi sahibi olmadıklarını, 11 öğretmen yeterince bilgi sahibi olduklarını, 2 öğretmen ise kısmen bilgi sahibi olduklarını belirtmişlerdir (Tablo 6).

Tablo 6. Öğretmenlerin Alternatif Ölçme ve Değerlendirme Yöntemi Konusunda Yeterince Bilgi Sahibi Olup Olmadıklarına Yönelik Düşünceleri

\begin{tabular}{llrr}
\hline Kategoriler & Alt Kodlar & f & \% \\
\hline \multirow{2}{*}{ Alternatif ölçme ve değerlendirme } & Evet & 11 & 44 \\
yöntemine yönelik bilgi sahibi olma & Hayır & 12 & 48 \\
& Kismen & 2 & 8
\end{tabular}

Alternatif ölçme ve değerlendirme yöntemine yönelik hizmet içi eğitim alma durumu ile ilgili olarak, görüşme yapılan 25 öğretmenin 16'sı hizmet içi eğitim almadıkları, 9'u ise hizmet içi eğitim aldıkları yönünde görüş bildirmişlerdir. Hizmet içi eğitim aldığı yönünde görüş bildiren öğretmenlere yöneltilen hizmet içi eğitim etkililiği sorusuna ise öğretmenlerin 5'i yetersiz, 2'si yeterli ve 2'si ise yüzeysel olduğu yönünde görüş bildirmişlerdir (tablo 7).

Tablo 7. Öğretmenlerin alternatif Ölçme ve Değerlendirme Yöntemiyle İlgili Hizmet İçi Eğitim Alma Durumlar1 ve Hizmet İçi Eğitimin Yeterliliğiyle İlgili Düşünceleri

\begin{tabular}{llcc}
\hline Kategoriler & Alt Kodlar & f & \% \\
\hline $\begin{array}{l}\text { Alternatif ölçme ve değerlendirme yöntemiyle } \\
\text { ilgili hizmet içi eğitim alma durumu }\end{array}$ & Evet & 9 & 36 \\
& Hayır & 16 & 64 \\
\hline \multirow{2}{*}{ Hizmet içi eğitimin yeterlilik durumu } & & & \\
& Yetersiz & 5 & 56 \\
& Yeterli & 2 & 22 \\
& Yüzeysel & 2 & 22 \\
\hline
\end{tabular}

Beden Eğitimi öğretmenleri yaygın olarak kullandıkları alternatif ölçme ve değerlendirme yöntemlerini sırasıyla performans değerlendirme (11), kontrol listesi, gösteri ve dereceleme ölçeği (6), gözlem (5), Görüşme, grup değerlendirme, akran değerlendirme ve öz değerlendirme (4), proje (3), rubrik (2) ve drama (1) olarak belirtmişlerdir (tablo 8).

Tablo 8. Öğretmenlerin Kullandıkları Alternatif Ölçme ve Değerlendirme Yöntemlerine Yönelik Düşünceleri

\begin{tabular}{llcc}
\hline Kategoriler & Ölçme Yöntemleri & f & \% \\
\hline & Performans Değerlendirme & 11 & 20 \\
& Kontrol Listesi & 6 & 11 \\
& Gösteri & 6 & 11 \\
& Dereceleme Ölçeği & 6 & 11 \\
\multirow{2}{*}{ Alternatif Ölçme ve } & Gözlem & 5 & 9 \\
& Görüşme & 4 & 7 \\
\hline
\end{tabular}




\begin{tabular}{llll}
\hline Değerlendirme Yöntemleri & Grup Değerlendirme & 4 & 7 \\
& Akran Değerlendirme & 4 & 7 \\
& Öz Değerlendirme & 4 & 7 \\
& Proje & 3 & 5 \\
& Rubrik & 2 & 3 \\
& Drama & 1 & 2 \\
\hline
\end{tabular}

Öğretmenlerin birçoğuna göre alternatif ölçme ve değerlendirme yöntemlerinin uygulanmasında yaşanan zorluklar; zaman yetersizliği yaşamaları (11), kalabalık sınıf (4), öğretmenlerin alan ve materyal sorunu yaşaması (4) ve çok uğraş gerektirmesi-bürokrasidir (4). Ayrıca öğretmenlerin bilgi eksikliği (3) ve evrak işinin-kağıt israfının fazla olması (3) da alternatif ölçme ve değerlendirme yöntemlerinin uygulanmasında yaşanan zorluklar arasında gösterilmektedir (Tablo 9).

Tablo 9. Öğretmenlerin Alternatif Ölçme ve Değerlendirme Yöntemlerini Uygularken Yaşadıkları Zorluklara Yönelik Düşünceleri

\begin{tabular}{l|lcc}
\hline Kategoriler & \multicolumn{1}{c}{ Alt Kodlar } & F & \% \\
\hline \multirow{2}{*}{$\begin{array}{l}\text { Alternatif ölçme ve } \\
\text { değerlendirme yöntemlerini }\end{array}$} & Zaman yetersizliği & 11 & 38 \\
uygularken karşılaşılan & Kalabalık sınıf & 4 & 14 \\
zorluklar & Alan-materyal eksikliği & 4 & 14 \\
& Uğraş gerektirmesi-bürokrasi & 4 & 14 \\
& Bilgi eksikliği & 3 & 10 \\
& Evrak çokluğu-kağıt israfi & 3 & 10 \\
\hline
\end{tabular}

\section{Tartışma ve Sonuç}

Araştırma sonuçlarına göre Beden Eğitimi öğretmenlerinin, alternatif ölçme ve değerlendirme yöntemleri arasında en s1k "gösteri" yöntemini daha sonra ise sira ile performans değerlendirme, gözlem, kontrol listesi, dereceleme ölçeği ve görüşme yöntemlerini diğer alternatif ölçme ve değerlendirme yöntemlerine göre sık kullandıkları belirlenmiştir. Genç (2008)'in Beden Eğitimi öğretmenleri ile Yiğit (2013)'in ise Türkçe öğretmenleri ile yaptı̆̆ çalışmada benzer sonuçlara ulaşmıştır.

Devlet ve özel okullarında görev yapan Beden Eğitimi öğretmenlerinin alternatif ölçme ve değerlendirme yöntemlerini kullanma sıklıkları arasında anlamlı bir fark bulunmazken Bağcı (2011), sınıf öğretmenlerinin çalıştıkları kurum türüne göre anlamlı bir fark bulmuştur. Bu farklılığın özel okulda görev yapan sınıf öğretmenleri lehine olarak açıklamıştır.

Hizmet içi eğitim almış ve almamış Beden Eğitimi öğretmenleri arasında genel olarak alternatif ölçme ve değerlendirme yöntemlerini kullanma sıklıkları açısından anlamlı bir fark söz konusudur. Alternatif ölçme ve değerlendirme yöntemleri konusunda hizmet içi eğitim almış 
Beden Eğitimi öğretmenlerinin hizmet içi eğitim almamış öğretmenlere göre alternatif ölçme ve değerlendirme yöntemlerini genel olarak daha sık kullandıkları söylenebilir. Benzer sonucu içeren Kılıç (2013)'ın İlköğretim öğretmenleri ile Yılmaz (2007)'ın ise Beden Eğitimi öğretmenleri ile yaptığı araştırmalarda öğretmenlerin alternatif ölçme ve değerlendirme uygulamalarına yönelik kullanma sıklıklarında ve görüşlerinde daha önce aldıkları hizmet içi eğitimin bir etkisi olduğu sonucuna varılmıştır. Tüm bu araştırmalar 1şığında ölçme ve değerlendirme yöntemleri ile ilgili hizmet içi eğitim almanın öğretmenler tarafından bu yöntemlerin kullanılma sıklığını arttıran bir değişken olduğu söylenebilir.

Beden Eğitimi öğretmenlerinin derslerinde kullandıkları ölçme değerlendirme yöntemlerini tercih etme nedenlerine yönelik görüşlerinin başında bu yöntemlerin kullanışlı ve uygun olması vardır. Ayrıca öğretmenler bu yöntemleri, programda var olduğu için (zorunluluktan), seviye belirlemek-öğrenciyi tanımak için, objektif ve güvenilir olduklarından, yeterli (verimli) olduklarından, somut veri elde etmeye yaradıklarından tercih ettiklerini belirtmişlerdir. $\mathrm{Bu}$ sonucu destekler nitelikteki çalışmada K1lıç (2013), İlköğretim birinci kademe öğretmenlerinin derslerinde kazanımların ölçülmesinde kullandıkları ölçme değerlendirme araçlarını tercih etme nedenlerine yönelik görüşlerini, programın öngördüğü ölçme araçları olması, bu araçların kullanışlı olması ve somut veri elde etmeye yaraması şeklinde sıralamıştır. Yine bu sonucu destekler nitelikteki bir çalışmada Algan (2008), İlköğretim 6. ve 7. sınıf Sosyal Bilgiler dersi öğretim programının ölçme ve değerlendirme öğesinin öğretmen görüşleri açısından incelenmesine yönelik araştırmasında, öğretmenlerin alternatif ölçme ve değerlendirme araçlarını kullanma nedenlerini, uygun olduğu için ve program öngördüğü için olarak tespit etmiştir.

Yapılan çalışmadan elde edilen sonuçlar ışığında, alternatif ölçme ve değerlendirme yöntemine yönelik yeterince bilgi sahibi olup olmama durumuna ilişkin olarak, Beden Eğitimi öğretmenlerinden kendilerini yeterli görenler ve yeterli görmeyenler hemen hemen eşit sayıdadır. Görüşme yapılan 25 öğretmenin 12'si alternatif ölçme ve değerlendirme yöntemine yönelik yeterince bilgi sahibi olmadıklarını, 11 öğretmen yeterince bilgi sahibi olduklarını, 2 öğretmen ise kısmen bilgi sahibi olduklarını belirtmişlerdir. Araştırmaya katılan öğretmenlerin yarıya yakınının alternatif ölçme ve değerlendirme yöntemlerine yönelik yeterince bilgi sahibi olmadığı tespit edilmiştir. Bu sonuçlara benzer nitelikteki araştırmalarda; Genç (2008), Beden Eğitimi öğretmenlerinin ölçme ve değerlendirme yeterlilik algılarının oranlarına bakmış, Beden Eğitimi öğretmenlerinin göreli olarak kendilerini yetersiz olarak algıladıklarını tespit etmiştir. 
Gelbal ve Kelecioğlu (2007)'nun ve Kanatlı (2008)'nın yaptığı araştırmalarda öğretmenlerin kendilerini geleneksel olarak adlandırılan ölçme yöntemleri dışındaki diğer yöntemlerde orta düzeyde ve kısmi anlamda yeterli gördüklerini tespit etmişlerdir.

Çakan (2004), Öğretmenlerin ölçme-değerlendirme uygulamaları ve yeterlik düzeyleri üzerine yaptığ1 araştırmasında, öğretmenlerin oldukça büyük bir kısmının ölçme ve değerlendirme konusunda kendilerini yetersiz ve eksik bulduklarını tespit etmiştir.

Alternatif ölçme ve değerlendirme yöntemine yönelik olarak Beden Eğitimi öğretmenlerinin büyük çoğunluğu hizmet içi eğitim almamıştır. Hizmet içi eğitim alan Beden Eğitimi öğretmenlerinin verilen eğitimin yeterliliğiyle ilgili görüşleri incelendiğinde, öğretmenlerin büyük çoğunluğu aldıkları eğitimlerin yetersiz ve yüzeysel olduğu yönünde görüş bildirmişlerdir.

Kılıç (2013), benzer sonuçlar içeren araştırmasında ilköğretim birinci kademe sınıf öğretmenlerinden otantik ölçme ve değerlendirme araçlarını kullanmaya yönelik olarak hizmet içi eğitim alan ile almayan öğretmen sayısının hemen hemen eşit olduğunu tespit etmiş, hizmet içi eğitim alan öğretmenlerin, verilen eğitimin yeterliliği ile ilgili görüşleri incelendiğinde "yetersizliği" , "uygulamaya dönük olmadığg" ve "yüzeysel" kaldığı yönünde görüş bildirdiklerini belirtmiştir.

Aşık (2009), Matematik öğretmenlerinin ölçme değerlendirme araçlarını kullanabilme düzeyleri ve yaklaşımları ile ilgili yaptığı araştırmada, Matematik öğretmenlerinin büyük bir çoğunluğunun ölçme değerlendirme ile ilgili herhangi bir hizmet içi kurs ya da programa katılmadığını tespit etmiştir. Yapılan araştırma sonuçları ile bu araştırma sonuçları bu yönüyle benzerlik göstermektedir.

Yapılan araştırmadan elde edilen sonuçlara göre, Beden Eğitimi öğretmenleri hangi alternatif ölçme ve değerlendirme yöntemleri kullandıklarına yönelik olarak, yaygın olarak kullandıkları alternatif ölçme ve değerlendirme yöntemlerinin; sırasıyla performans değerlendirme, kontrol listesi, gösteri dereceleme ölçeği, gözlem, görüşme, grup değerlendirme, akran değerlendirme, öz değerlendirme, proje, rubrik ve drama olarak belirtmişlerdir. Ayrıca birçok alternatif ölçme ve değerlendirme yönteminin derslerde kullanılmaması da dikkat çekici bir noktadır. Beden Eğitimi dersinin doğası gereği uygulama ağırlıklı bir ders olduğu düşünüldüğünde, araştırma sonucuna göre Beden Eğitimi öğretmenlerinin yaygın olarak kullandıkları alternatif ölçme ve 
değerlendirme yöntemlerinin uygulamalı olarak yapılan bir değerlendirmeye daha verimli katkı sağlayacağı düşünülebilir.

Benzer sonuçlar içeren çalışmalarda Algan (2008), öğretmenlerin sık sık kullandıkları ölçme değerlendirme araçları arasında en çok kullanılan alternatif ölçme ve değerlendirme yöntemlerinin; performans değerlendirme ve portfolyo olduğunu tespit etmiştir. Kanatlı (2008), Alternatif ölçme ve değerlendirme teknikleri konusunda sınıf öğretmenlerinin görüşlerinin değerlendirilmesine yönelik yaptığı araştırmada, öğretmenlerin en çok kullandıkları alternatif ölçme ve değerlendirme tekniklerinin başında performans ödevleri, proje çalışmaları ve öğrenci ürün dosyaları gelmektedir. Yiğit (2013), öğretmenlerin en sık kullandığı alternatif ölçme değerlendirme yöntemlerinin sirasıyla performans görevi ve proje olduğu sonucunu elde etmiştir. Ayrıca çalışmada, performans görevini hiç kullanmayan veya nadiren kullanan öğretmenin bulunmadığı, projeyi ise hiç kullanmayan öğretmenin bulunmadığı görülmüştür.

Elde edilen sonuçlara göre, Beden Eğitimi öğretmenlerinin alternatif ölçme değerlendirme yöntemlerini uygularken yaşadıkları en büyük zorluğun, "zaman yetersizliği" konusu olduğunu belirtmişlerdir. Ayrıca öğretmenler, "kalabalık sınıf", "alan-materyal eksikliği", "uğraş gerektirmesi-bürokrasi", "bilgi eksikliği", "evrak çokluğu-kağıt israfi" gibi konuların uygulama aşamasında karşılaşılan diğer güçlükler olduğu tespit edilmiştir.

Benzer nitelikte sonuçlar içeren Kılıç (2013)'ın yaptığı araştırmada, öğretmenlerin otantik ölçme değerlendirme yöntemlerini uygularken en çok karşılaştıkları zorluk olarak "zaman yetersizliği" konusunda görüş bildirdiklerini belirtmiştir. Ayrıca öğretmenlere göre "öğrencilerin uyum sorunu yaşaması", "kaynak sıkıntısı" ve "kalabalık sınıflar" da uygulama aşamasında karşılaşılan ve öne çıkan diğer zorluklar olarak tespit edilmiştir.

Gelbal ve Kelecioğlu (2007), yaptıkları araştırmada, öğretmenlerin yarısının ölçme yöntemlerini kullanmada sıkıntı yaşamadıklarını tespit etmişlerdir. Sorunla karşılaşan öğretmenlerin ise daha çok, "sınıfların kalabalık oluşu", "zaman yetersizliği" ve "hazırlamasının zorluğunu" sorun olarak gördüklerini belirtmişlerdir. Bu araştırmadaki sonuçlar da yapılan araştırmadan elde edilen sonuçlarla benzerlik göstermektedir.

Sağlam (2013), yaptığı araştırmada ise, alternatif ölçme değerlendirme yöntemlerini kullanırken sınıfların kalabalık olmasının öğretmenlerin karşılaştıkları en büyük sorun olduğunu tespit etmiştir. Ayrıca araştırma sonunda, alternatif ölçme ve değerlendirme yöntemlerinin yeterince kullanılamamasının sebebi olarak zaman yetersizliği gösterilmiştir. 
Algan (2008)'ın yaptığı araştırmada, öğretmenlerin yarısı alternatif ölçme ve değerlendirme araçlarını uygularken karşılaştıkları en büyük sorunun: "Uygulamanın çok fazla zaman alması" olduğunu belirtmişlerdir. Öğretmenlerle yapılan görüşmelerde, öğretmenlerin çoğu, programdaki etkinliklerin, konuların ve alternatif değerlendirme araçlarının çok fazla ve çeşitli olması nedeniyle zaman problemi yaşadıklarını ve birçok alternatif ölçme değerlendirme aracını bu sebeple kullanamadıklarını belirtmişlerdir.

Sonuç olarak literatürdeki benzer araştırmalar da dikkate alındığında öğretmenlerin alternatif ölçme ve değerlendirme yöntemlerini uygularken karşılaştıkları en büyük sorunun "zaman ve kalabalık sınıflar" olduğu; öğretmenlerin derslerinde kullandıkları ölçme değerlendirme yöntemlerini tercih etme nedenlerine yönelik görüşlerinin başında bu yöntemlerin kullanışlı ve uygun olması, alternatif ölçme ve değerlendirme yöntemleri konusunda hizmet içi eğitim almış Beden Eğitimi öğretmenlerinin hizmet içi eğitim almamış öğretmenlere göre alternatif ölçme ve değerlendirme yöntemlerini genel olarak daha sık kullandıkları ve her iki okul türünde de görev yapan Beden Eğitimi öğretmenlerinin alternatif ölçme ve değerlendirme yöntemlerini genel olarak benzer sıklıkta kullandıkları söylenebilir.

\section{Öneriler}

$\mathrm{Bu}$ araştırmada hem nicel hem nitel veriler üzerinden bir durum tespiti yapılmıştır. Yeni yapılacak çalışmalarda ilave olarak sınıf içi uygulamaların yapılması ve dokümanların incelemesinin yapılması yoluyla daha detaylı sonuçlar ortaya konulabilir. Beden Eğitimi öğretmenlerinin alternatif ölçme değerlendirme yöntemlerini uygulama aşamasında yaşadıkları zaman sorununu aşma amacıyla MEB'in Beden Eğitimi dersinin, haftalık ders saati sayısının artırılması konusunda çalışmalar yapması ve konuyla ilgili daha fazla hizmet içi eğitim faaliyeti düzenlemesi faydalı olabilir.

Beden Eğitimi öğretmenlerinin alternatif ölçme ve değerlendirme yöntemlerine ilişkin olarak hizmet içi eğitim almaları önemli bir husustur. Konuyla ilgili MEB bünyesindeki ölçme değerlendirme birimi uzmanlarının, alternatif ölçme ve değerlendirme yöntemleri ile ilgili olarak uygulamalı seminerlerin verilmesinin ve bu tarz seminerlerin sayısının artırılmasının faydalı olacağı düşünülmektedir. Alternatif ölçme ve değerlendirme yöntemlerinin uygulanmasında kalabalık sınıf mevcudu bir sorun olarak görünmektedir. MEB'in okullardaki sınıf mevcutlarını azaltıcı çalışmalar yapması, alternatif ölçme ve değerlendirme yöntemlerinin öğretmenler tarafindan daha kaliteli bir şekilde uygulayabilmesi aşamasında faydalı olabilir. 
Alternatif ölçme ve değerlendirme yöntemlerinin uygulama aşamasında, hem öğretmenlerin hem de öğrencilerin alan ve materyal kullanımı önemli bir yer tutmaktadır. Bu nedenle okullar materyal donanımı ve spor salonu gibi özellikler bakımından geliştirilmesi faydalı olabilir.. Okul idarecilerinin, öğretmenlerin alternatif ölçme ve değerlendirme yöntemlerini sınıf içinde tam anlamıyla uygulayabilmeleri için araç-gereç, materyal, fotokopi, vb. eksiklikleri tamamlamalarının gerekli olduğu düşünülmektedir.

\section{Kaynakça}

1. Algan, S. (2008). Illköğretim 6. ve 7. sinıf sosyal bilgiler dersi öğretim programının ölçme ve değerlendirme öğesinin ögretmen görüşleri açısından incelenmesi. Çukurova Üniversitesi, Sosyal Bilimler Enstitüsü, İlköğretim Anabilim Dalı, Yüksek Lisans Tezi. Adana.

2. Aşık, İ. (2009). Yeni ilköğretim programlarının öngördüğ̈̈ tamamlayıcı ölçme ve değerlendirme teknikleri hakkındaki öğretmen görüşlerinin değerlendirilmesi. Marmara Üniversitesi, Eğitim Bilimleri Enstitüsü, İlköğretim Anabilim Dalı, İlköğretim Matematik Öğretmenliği Bilim Dalı, Yüksek Lisans Tezi. İstanbul.

3. Bağc1, M. S. (2011). Illköğretim sınıf öğretmenlerinin alternatif ölçme değerlendirme tekniklerini etkin kullanabilme yeterliliklerinin araştırılması. Marmara Üniversitesi, Eğitim Bilimleri Enstitüsü, İlköğretim Anabilim Dalı, Sınıf Öğretmenliği Bilim Dalı, Yüksek Lisans Tezi. İstanbul.

4. Çakan, M. (2004). Öğretmenlerin ölçme-değerlendirme uygulamaları ve yeterlik düzeyleri: İlk ve ortaöğretim. Ankara Üniversitesi, Ĕ̆itim Fakültesi Dergisi 37:2 99114

5. Doğan, D., Kutlu, Ö. ve Karakaya, İ. (2014). Ölçme ve değerlendirme performansa ve portfolyoya dayall durum belirleme Ankara: Pegem akademi

6. Ertürk, S. (2013). Eğitimde program geliştirme. Ankara: Edge Akademi.

7. Geçit, Y. (2012). "Geleneksel ölçme araçlarl ve özellikleri" (Editörler: Küçük M. ve Geçit Y.) Eğitimde ölçme ve değerlendirme. Ankara: Nobel Akademik Yayıncılık.

8. Gelbal, S. ve Kelecioğlu, H. (2007). Öğretmenlerin ölçme ve değerlendirme yöntemleri hakkındaki yeterlik algıları ve karşılaştıkları sorunlar. Hacettepe Üniversitesi Ĕ̈itim Fakültesi Dergisi 33: 135-145

9. Genç, N. (2008). Beden ĕgitimi öğretmenlerinin ölçme değerlendirme uygulamalarl ve yeterlik algıları.Mersin Üniversitesi, Sağlık Bilimleri Enstitüsü, Beden Eğitimi ve Spor Anabilim Dalı, Yüksek Lisans Tezi, Mersin.

10. Kanatlı, F. (2008). Alternatif ölçme ve değerlendirme teknikleri konusunda sinıf ögretmenlerinin görüşlerinin değerlendirilmesi. Mustafa Kemal Üniversitesi, Sosyal Bilimler Enstitüsü, İlköğretim Anabilim Dalı, Yüksek Lisans Tezi. Hatay.

11. Karasar, N. (2005). Bilimsel araştırma yöntemleri. Ankara: Nobel yayın dağıtım. 
12. Kayapınar, F. Ç. ve Savaş, B. (2012). İlk + Orta okullarda beden eğitimi dersinde ölçme ve değerlendirme. Ankara: Anı yayıncılık

13. Kılıç, R. (2014). İlköğretim birinci kademe öğretmenlerinin otantik ölçme değerlendirme yöntemleriyle ilgili bilgi, tutum ve görüşlerinin değerlendirilmesi. Marmara Üniversitesi, Eğitim Bilimleri Enstitüsü, İlköğretim Anabilim Dalı, $\quad$ Sınıf Öğretmenliği Bilim Dalı, Doktora Tezi. İstanbul.

14. M.E.B (2006). Illköğretim beden ĕgitimi dersi 1-8. sinıflar ögretim programı Ankara: Milli Eğitim Bakanlığı, TTKB.

15. M.E.B (2015). Beden eğitimi ve spor dersi 5-8. sinıflar öğretim programı uygulama kılavuzu. Ankara: Milli Eğitim Bakanlığı, TTKB.

16. Miles, M. B. \& Huberman, A. M. (1994). Qualitative data analysis. CA: Sage Publications.

17. Sağlam, F. Ş. (2013). İlköğretim matematik öğretmenlerinin alternatif ölçme değerlendirme yöntem ve araçlarını kullanabilme yeterlikleri, karşılaştıkları sorunlar ve çözüm önerileri. Yüzüncü Y1l Üniversitesi, Eğitim Bilimleri Enstitüsü, Ortaöğretim Fen ve Matematik Alanları Eğitimi Anabilim Dalı, Yüksek Lisans Tezi. Van.

18. Y1lmaz, G. (2007). Ankara'daki merkez ilköğretim okullarında görevli beden eğitimi ve spor ögretmenlerinin ölçme ve değerlendirme tekniklerinin uygulanışına ilişkin görüşleri. Ankara Üniversitesi, Sağlık Bilimleri Enstitüsü, Beden Eğitimi ve Spor Anabilim Dalı, Yüksek Lisans Tezi. Ankara.

19. Yiğit, F. (2013). Illköğretim 6, 7 ve 8. sinıf Türkçe dersi ögrretim programındaki alternatif ölçme-değerlendirme yöntemlerine yönelik ögretmen görüşlerinin değerlendirilmesi. Karadeniz Teknik Üniversitesi, Eğitim Bilimleri Enstitüsü, Türkçe Eğitimi Anabilim Dalı, Türkçe Eğitimi Bilim Dalı, Yüksek Lisans Tezi. 